\title{
The price of unity: the transformation of Germany and Eastern Europe after 1989
}

\author{
Philipp Ther'
}

This article adopts a comparative perspective and focuses on the economic reforms that were implemented in Germany and Eastern Europe during and after German unification in 1990. After the collapse of communism, most politicians and economists considered neoliberal reforms based on deregulation, liberalization and privatization as the only viable model. Although the reforms in eastern Germany were not labeled as such, they amounted to a "shock therapy," much like in neighboring Poland. Radical privatization and hasty liberalization, in combination with monetary union coming into force in July 1990, resulted in the closure of many enterprises and mass unemployment. The German government tried to compensate the "Iosers of transformation" with welfare payments, but this resulted in a systemic crisis of united Germany that eventually led to a second round of neoliberal reforms under Federal Chancellor Gerhard Schröder's center-left coalition government from 2001 to 2005. The widening social gaps and the fear of social dislocation have contributed to the rise of right-wing populist parties both in Germany and in East Central European countries like Poland.

\section{JEL classification: F63, N14, O52, P20}

Keywords: transformation, neoliberalism, postcommunist reforms, shock therapy, populism, German unification

Anniversaries of historic events make us look at history from a perspective shaped all the more by the present. In 2009 and even in 2014, reviews of transformation and of the "shock therapies" of the 1990s were still mostly or overwhelmingly positive. The global crisis of 2008/09 and recent electoral successes of right-wing populists and nationalists have called into question neoliberal narratives of economic success and even the - in Hannah Arendt's words - liberal revolutions of 1989. ${ }^{2}$ In 2009, the German government organized a huge Festival of Freedom in front of the Brandenburg Gate in Berlin to celebrate the $20^{\text {th }}$ anniversary of the presumed annus mirabilis. On this occasion, artists were invited to design plastic replicas of pieces of the Berlin Wall, which were lined up and then made to collapse, creating a staged domino effect that symbolized the end of communism. What it rather looked like, however, was an involuntary reference to the global financial crisis. In the end, a domino effect of the bankruptcy of Lehman Brothers on other banks has been prevented, as has the collapse of entire economies in Central, Eastern and Southeastern Europe (CESEE) after the end of communism. Although another depression like the one in the 1930s was averted, the financial crisis and the subsequent euro crisis delegitimized the order created in 1989. Eastern and Southern Europe were hit particularly hard, which called into question European integration a project that may, in a way, be considered globalization on a smaller scale. Against this background, the 2014 review of European transformation was - yet again surprisingly positive. Harvard economist Andrei Shleifer and Californian political

\footnotetext{
University of Vienna, philipp.ther@univie.ac.at. Opinions expressed by the authors of studies do not necessarily reflect the official viewpoint of the Oesterreichische Nationalbank, the Eurosystem or the University of Vienna.

2 Of course, Arendt had not yet discussed the events of 1989 in her book "On Revolution" (Arendt, 1963), but they fit in with her pattern of constitutional or liberal revolutions laid down therein.
} 
scientist Daniel Treisman chose "Normal Countries" as the title of their 2014 review of the transformation process (Shleifer and Treisman, 2014).

Anyone who experienced the "normalization" era in Czechoslovakia that followed the suppression of the Prague Spring would have severe doubts about the term "normal." What is considered "normal" always depends on the prevailing social and political order. Shleifer and Treisman (2014) referred to the synchronous development of former communist countries into free market economies and liberal democracies, confirming Francis Fukuyama's thesis of the end of history. Thanks to comprehensive modernization, the authors argued in the journal Foreign Affairs (Shleifer and Treisman, 2014), the postcommunist countries had become normal countries and in some ways better than normal. Shleifer and Treisman (2014) praised radical reforms - and not gradual reforms - as the best variant of transformation.

The present article discusses a case of postcommunist transformation that was mostly omitted from the English-language literature on CESEE but which, nonetheless, can be regarded as another testing ground for shock therapies: the former German Democratic Republic (GDR). The example of the GDR is particularly interesting because it shows that transformation did not stop at Europe's former East-West divide but that the underlying economic principles and the economic policies they informed had strong repercussions on the West. In the following, we will refer to this type of feedback as "cotransformation" - a phenomenon that had a particularly heavy impact on Germany because of unification. In this sense, Germany is a special case all the more deserving of closer examination.

Germany was rather swift in overcoming the financial and economic crisis of 2008/09 and has since been internationally perceived as a model of economic success. A look back to the late 1990s, however, shows how quickly an upswing can turn into a decline - and vice versa. In 1999, the Economist referred to Germany as "the sick man of the euro" (Economist, 1999). At that time, Germany seemed to be caught in a vicious circle of low growth, rising unemployment and government debt (see Ther, 2016a).

Germany's crisis at the time was not least a result of economic policy decisions taken in 1990. In the subsequent decade, the bankrupt GDR and the Socialist Unity Party of Germany (SED) were repeatedly blamed for the economic problems in eastern Germany. What is often ignored, however, is that the main actors of German transformation came from the West. This had to do with the course of German unification, which entailed an extensive exchange of elites in eastern Germany. The electoral success of the Alternative for Germany (AfD) in eastern Germany and, most recently, Bochum historian Marcus Böick's 2018 history of the East German privatization agency, Treuhandanstalt, have triggered a long overdue debate about the reform policies of the early 1990s and, particularly, privatization. Especially as a historian, one should be wary about the wisdom of hindsight - yet, one needs also to be very critical of the Thatcherite slogan stating that "there is no alternative."

The economic reforms in the five "new Länder" - which is what they were called in 1990 in a slightly paternalistic manner - aimed at a swift alignment with the West. Not only the Federal Republic of Germany but the entire Western world saw the outcome of the Cold War as a confirmation of the superiority of their political and economic system. Socialism has lost, capitalism has won - this is how renowned economist Robert Heilbroner put it in The New Yorker magazine in early 
1989 (Heilbroner, 1989, p. 98). Not much later, the International Monetary Fund (IMF), the World Bank and the U.S. Department of the Treasury adopted the Washington Consensus. This economic standard prescription for crisis countries arranged as a decalogue very much like the Ten Commandments - was first intended for debt-ridden Latin American countries but was then applied, above all, to postcommunist Europe. It starts out with the objective of macroeconomic stabilization - in fact, this always meant austerity programs - and leads on to the triad of liberalization, deregulation and privatization. By way of conclusion, the Washington Consensus makes a case for foreign direct investment (FDI) and global financial capitalism (for details on the Washington Consensus, see Ther 2016b).

\section{The year 1989 from a global perspective}

The Washington Consensus was part of the global transformation that took place in 1989, as was the democratization of Chile. Chile is important in this context because advisors associated with the Chicago School of Economics were active there. International observers therefore attributed Chile's long recovery following the 1982 Latin American debt crisis mostly to radical privatization, internal and external liberalization and deregulation (only the profitable copper mines remained in state ownership). Chile marks the beginning of the neoliberal "success stories" that later had a strong impact on postcommunist Europe. On closer examination, it is questionable whether Chile's upswing, which lasted until the Asian financial crisis of 1998, can be attributed to the neoliberal economic policy stance under Augusto Pinochet or rather to the Christian and social democrats' economic policy after 1989 , which strove for "social equilibrium" by actively fighting poverty and increasing purchasing power.

The ideas of the Washington Consensus were taken up in Europe faster than its authors could have anticipated. In June 1989, Solidarnos'ć won a landslide victory in the first free elections in postwar Poland, and the communists were happy to let the opposition take over the government so it would be blamed for the economic malaise (which is exactly what happened in the 1993 parliamentary elections). In the summer and fall of 1989, the country's first postcommunist finance minister, Leszek Balcerowicz, developed a reform plan which was soon to be named after him. What came first in the Balcerowicz Plan was macroeconomic stabilization, as Poland was suffering from high inflation that began to show signs of expanding into hyperinflation, unsustainable external debt (more than $70 \%$ of GDP, with repayment being impossible given the country's trade deficit alone) and other consequences of its dysfunctional planned economy.

As the Polish version of perestroika, the Wilczek reforms, had failed, prominent experts had already begun to turn toward radical reforms at the end of 1988. As early as in 1988, the weekly paper Polityka reported on the growing influence of

\footnotetext{
The phrase was coined by Alejandro Foxley, Chile's first postdictatorial finance minister, whose views were influenced by Catholic social teaching. For details on his reform concepts, see various documents that can be found in the World Bank archive's files on Chile; in this context, in particular, an 11-page manifest from 1988 and the records of conversations on the occasion of Foxley's visit at the World Bank in 1989 stored in the World Bank archive, World Bank File 16435 (Chile - Lending, Economy and Program (LEAP) - General - Volume 2), the annex to the World Bank report of October 18, 1988, and World Bank File 16436 (Chile - Lending, Economy and Program (LEAP) - General - Volume 3), and the report of October 30, 1989 (all World Bank files listed here are without pagination). On Chile's economic policy and the historical changes of 1989, see also Ffrench-Davis (2010).
} 
"Eastern Thatcherites" (see Borkowski, 1988, p. 1, p. 4). Much like the Washington Consensus, the Balcerowicz Plan aimed at comprehensive privatization and swift internal and external liberalization. Although it was clear that the reforms would lead to massive social cutbacks and dismissals and that they would be accompanied by a wage limitation law, the majority of the left wing of Solidarnośc and the followers of Catholic social teaching approved. We can thus speak of a "Warsaw Consensus," which was - like its role model - arranged as a decalogue. ${ }^{4}$

The effects of the reforms were mixed. Inflation was indeed brought under control but GDP went down by a total of $18 \%$ in 1990 and 1991. Industrial production declined by almost one-third, and wage limitations dampened demand over a sustained period. Another effect were huge numbers of unemployed: In 1992, 2.3 million people in Poland were without employment - 13.5\% of the labor force. ${ }^{5}$ Critics like Grzegorz Kołodko, later postcommunist finance minister,

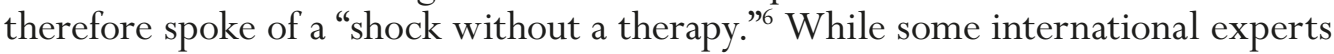
would have approved of an even more radical course, Balcerowicz made certain concessions. For instance, he reduced the speed at which large enterprises were privatized; so all in all, he acted in a rather pragmatic way. In 1992, the economy started to pick up again, and Poland was the first of the former Eastern bloc countries to recover from the deep recession of 1989-91. Thus, the shock therapy was internationally perceived to be a success. At the political level, it was not: The parties that had evolved from Solidarność lost the 1993 elections against the postcommunists. These, however, did not take back the reforms as previously promised but only mitigated them.

Turning to Germany, Theo Waigel, West German finance minister in 1989, and Wolfgang Schäuble, one of the main authors of the Unification Treaty, were neither among the followers of the neoliberal Chicago School of Economics nor in favor of a "shock therapy." Both ministers of the center-right government were Christian Democrats and adherents of ordoliberalism and the German model of a "social market economy." But apart from social cushioning, stronger government regulation and a system of collective wage agreements, the neoliberal and ordoliberal reform concepts were largely congruent. In Czechoslovakia, the Chicago School had direct influence; Nobel Memorial Prize winner Milton Friedman, for instance, toured East Central Europe in 1990 and found a particularly enthusiastic supporter in Václav Klaus, then minister of finance in Czechoslovakia. ${ }^{7}$ The latter's model of voucher privatization was, in turn, taken up in Russia. It did not work there, however. Rather, it led to the emergence of oligarchs, who bought up most of the vouchers, distorted privatization through insider deals and have dominated the Russian economy ever since.

${ }^{4}$ For details on the contemporary rationale behind the reforms, see Balcerowicz (1992). In this book, Balcerowicz uses the word "shock," which he had prudently avoided in 1989. For details on the American consultants' view of the design of these radical reforms, see Lipton and Sachs (1990, pp. 47-66).

See the figures in wiiw (2012), table II/1.7. In December 1989, Balcerowicz had expected a slight decrease in demand and a limited rise in unemployment (see Balcerowicz, 1989, p. 1, p. 5, in particular column 2 on p. 1).

${ }^{6}$ For details, see also Kołodko (2000).

7 See also the television documentary called Free to Choose, which Friedman produced in 1990 for the Public Broadcasting Service (PBS), a U.S. public television broadcaster. In episode 4 on Freedom and Prosperity, Friedman traveled to East Central Europe. The episode also features Václav Klaus, who readily confirms Friedman's teachings. The program is accessible online at www.youtube.com/watch? $\mathrm{v}=12 \mathrm{~h} 50 R 1 \mathrm{QX} 3 \mathrm{Y}$ (retrieved on November 11, 2018). Klaus appears as of minute 20. 


\section{The German shock therapy}

Radical economic reforms can be pushed through most easily if the economies concerned are on the brink of collapse. This was the case, without doubt, in the last year of the GDR. The exchange rate of the East German mark (DDM) to the Deutsche mark (DEM) declined to 7:1 in the fall of 1989, and went even lower, at times, in the winter that followed. This meant that East Germany's high foreign debt could no longer be serviced. The asymmetry of power between West and East was reflected, inter alia, in the type of reunification that was chosen: German reunification was executed as an "accession" of the five "new Länder" pursuant to Article 23 Basic Law - and not pursuant to Article 146, which was actually intended for such a scenario. This means that what we are dealing with here was in fact an enlargement of West Germany and not a unification of two equal states.

The sharp fall of the East German mark mirrored the economic problems of the GDR and the gloomy expectations of its future. However, depreciation had already started much earlier. While in the 1980s, the GDR insisted on the parity of the East German mark - both officially and in the compulsory exchange of currency for West Germans - the GDR's foreign trade bank halved the internal clearing rate to the Deutsche mark (like the other currencies of the communist countries, the East German mark was not convertible). In 1988, the foreign trade bank's internal exchange rate, which was kept strictly secret, came to no more than DDM 4.40 to DEM 1, because the GDR was not able to sell its goods at a higher exchange rate.

Illegal moneychangers in the backyards of East Berlin or Leipzig paid roughly the same rate; the black market thus reflected the economic situation more accurately than the official exchange rates. When the East German mark depreciated after the fall of the Berlin Wall, wages and salaries in the GDR, which were low at any rate, depreciated even further. Like in Poland or Czechoslovakia, a tank of fuel or a broken washing machine often were enough to strain a household's budget. This economic crash, together with the general uncertainty, explains why the call "We are one people" grew louder and louder in the fall and winter of 1989/90.

By the spring of 1990, a new slogan had taken hold: "Kommt die D-Mark, bleiben wir, kommt sie nicht, geh'n wir zu ihr!" "If we get the Deutsche mark, we'll stay; if we don't, we'll come get it.") The last part of the slogan referred to the threat of mass emigration from the GDR to escape economic misery. In the East German election campaigns of 1990, the Christian Democratic Union (CDU) offered an obvious way forward: quick reunification and, en route, economic and monetary union with West Germany. The CDU kept this electoral promise: On July 1, 1990, the Deutsche mark - symbol of prosperity - became the official currency of East Germany, prompting celebrations in Berlin, Leipzig and other cities. But how come a 1:1 exchange rate was applied, given the rapid depreciation of the East German mark after the fall of the Berlin Wall?

The Deutsche Bundesbank cautioned against the economic risk of too strong appreciation, arguing the case for a 2:1 exchange rate. Representatives of the State Bank of the GDR even called for a 7:1 exchange rate as this would have corresponded to the country's economic power and would thus have enabled eastern German companies to compete with West German industry. ${ }^{8}$ In the end, however,

For details on the calculation of the exchange rate, see Sinn and Sinn (1992). For details on the proposal by the State Bank of the GDR, see an interview by Deutschlandfunk of February 28, 2015, with the bank's vice president Edgar Most, accessible online at www.deutschlandfunk.de/25-jahre-treuhandanstalt-eine-einzigeschweinerei.694.de.html?dram:article_id=312882 (retrieved on February 20, 2019). 
the West German government under Federal Chancellor Helmut Kohl took a political decision and opted for the 1:1 exchange rate (the only exception being large savings deposits and company debts, to which a rate of 1:2 or 1:3 applied, respectively). This move helped the Christian Democrats win the first elections in unified Germany in the fall of 1990. A key argument used in public debates was that it served to prevent another wave of mass migration from eastern to western Germany. The freedom of movement indeed distinguished the situation in Germany from that of the other postcommunist countries.

\section{Germany's special path}

Given their focus on national unity and traditional orientation toward the West, the western German elites turned a blind eye on what was happening in their immediate neighborhood. The Czechoslovak koruna (CSK), the currency of Czechoslovakia, which was almost as wealthy as the GDR, also dropped dramatically in the winter of 1989/90. Its exchange rate declined to the three-times lower black market rate, i.e. to around CSK 15 to DEM 1. Unlike the West German government, the Czechoslovak government accepted this depreciation. Following the example of Poland and Hungary, Minister of Finance Václav Klaus intended to keep the national currency cheap in order to boost exports, save the large, formerly socialist enterprises and keep unemployment down. This strategy worked rather well until the Czech banking crisis of 1996. While the currency depreciation made Czechoslovak exports cheaper by a factor of around 3 (that is, when taking the official exchange rate in 1989 as a point of reference), German monetary union meant a fourfold price increase for East German exports compared with the 1988 clearing rate. This automatically meant that eastern German products - a Wartburg car, to name a typical example - would never be able to compete with a Škoda or any other Czech product and that production shifts in industry would most likely pass by eastern Germany.

Monetary union was followed by a second shock to the eastern German economy: the quick liberalization of foreign trade. When East Germany joined the Federal Republic of Germany and, by doing so, the European Community, all trade barriers fell - a step that is laid down, in principle, in the Washington Consensus. The eastern German economy was not able to cope with this competition. From this perspective, joining the EU not before 2004 was an advantage for the other postcommunist countries. But still, the conditions for integration into the European single market and the world market were a lot less protective than in the three decades after 1945, when Western Europe was reconstructed and West Germany experienced its Wirtschaftswunder.

The third particularity of German transformation was radical privatization, which disregarded a basic market mechanism. There were times when Treuhandanstalt, the German government agency responsible for privatization, was in charge of 12,534 enterprises with more than four million employees. More than 10,000 enterprises were sold until the end of 1992 alone, i.e. in a period of only two years (for details, also on data provided in the following, see Böick, 2018). If such huge numbers of enterprises are put to market, it is clear that their sales prices will drop dramatically. And indeed, instead of the expected profit of around DEM 600 billion, Treuhandanstalt recorded losses in the amount of DEM 270 billion, i.e. more than DEM 15,000 per (former) GDR citizen. At the end of 1994, Germany's federal government proudly 
announced the dissolution of Treuhandanstalt, stating that privatization had been completed. But with most privatized enterprises, production was simply discontinued. In the enterprises sold by Treuhandanstalt, only every fourth job was preserved according to Böick's (2018) calculations. To this day, many mostly medium-sized towns whose prosperity had depended on a small number of large factories have not been able to cope with this structural break.

These critical remarks on Germany's shock therapy - which, unlike Poland's, never became known by that name - prompt the question of whether there would have been any alternatives. In the early 1990s, this was of course denied; "there is no alternative" was the prevailing attitude toward the reforms. Maintaining a realistic exchange rate during monetary union would have disappointed many voters in eastern Germany and created an even wider pay and pensions gap. Would this have been enough for even more people to move from eastern Germany to western Germany, as had been feared? This question cannot be answered ex post. It is a fact, however, that despite the cushioning of the reforms and despite high transfer payments from western Germany to eastern Germany, 1.4 million people moved from the eastern to the western German Länder in only four years (on East-West migration, see Martens, 2010). In this respect, the wider objective of monetary union, namely to keep the people in eastern Germany, was not achieved.

When we look beyond Germany, we see that there were indeed alternatives to quick privatization. In Poland, the Czech Republic and in particular in Slovakia, for instance, large enterprises of strategic importance continued to be run under state management and sold only at the end of the 1990s. This did not mean that these enterprises continued to make losses like they did before 1989; they had to work for profit, which some of them actually succeeded at.

A measure to which there most likely was "no alternative" was the liberalization of foreign trade and the opening of the eastern German market. Slowing down these processes would probably have been possible only within a special customs area, with different import restrictions or within a special economic zone. The People's Republic of China applied such measures in a number of regions; in the EU, however, these would have been difficult to enforce. Moreover, a special economic zone in eastern Germany or in parts of the east German Länder would have entailed stronger economic competition for western German producers - something neither politicians nor enterprises in western Germany had any interest in.

Tough competition from the West also hit those former GDR citizens who had started their own businesses. Compared with other professional groups and with new entrepreneurs in Poland and the Czech Republic, they fared worse. Often, the self-employed experienced a social decline; in the worst case, their businesses went bankrupt (see Diewald, 2016). The professional group that suffered the least were civil servants - unless they lost their positions because they had secretly collaborated with the State Security Service (Stasi) or held a prominent position in the SED. Through monetary union and the expansion of collective wage agreements to include the five "new Länder," eastern German civil servants saw their salaries climb substantially. This was all the more true for the many western German civil servants that were sent to work in eastern Germany. They even received special bonus payments (colloquially called Buschzulage) for working in eastern Germany. However, the German federal government lacked further visions about which social classes and elites, apart from imported civil servants, were to carry eastern Germany forward. 
The price for this mixture of national self-centeredness, neoliberalism and lack of visions for society was an unprecedented economic downturn. By the mid-1990s, industrial production in eastern Germany had dropped to $27 \%$ of its 1988 level. No other postcommunist country in Europe, not even war-torn Bosnia and Herzegovina, saw a comparably dramatic decline (see Norkus, 2012, p. 80). As a result, 1.4 million people from the "new Länder" left their homes in the period up to 1994, as already mentioned. This number corresponded almost exactly to that of newly established businesses in Czechoslovakia - the ČSSR had almost as many inhabitants as the GDR, which allows for comparisons of the two countries. In Poland and in Hungary, too, many people started their own businesses. Altogether, around four million businesses were newly established in the Visegrád countries in the first five years after 1989. ${ }^{9}$ In the GDR, the number of newly founded businesses was significantly lower.

The collapse of the eastern German economy strained the government budget and, in particular, social security funds which, directly or indirectly, had to provide for the millions of unemployed. The government issued early retirement programs, the cost of which was mostly imposed on pension funds, and health insurance providers had to make high transfer payments as well. But pacifying the eastern German "losers of transformation" by social benefits could not be financed in the long run (for details on the crisis of the German welfare state, see Ritter, 2006). The continuous rise of social security contributions, taxes and government debt continued in the 1990s - at the expense of economic growth throughout Germany. The united Germany had reached a dead end; Federal Chancellor Helmut Kohl lost the 1998 federal elections, and Gerhard Schröder won - not least by promising reforms.

\section{Second-stage reforms and cotransformation}

Schröder's center-left coalition government, formed by the Social Democratic Party of Germany (SPD) and Alliance 90/The Greens, then took a series of measures that had already been implemented in East Central Europe at an earlier stage. These included the partial privatization of pension funds and labor market liberalization. For some time, Germany saw lively discussions about introducing a flat $\operatorname{tax}^{10}$ on wages and income and an otherwise strongly simplified tax system as well as about collecting healthcare contributions instead of income-related health insurance contributions. With regard to postcommunist Europe, we may speak of a cotransformation that originated in the problems of running eastern Germany and eventually impacted on former West Germany. Of course, reforms and policy models in the West were also a point of reference, especially the social reforms enacted by Tony Blair's New Labour.

What was new about the red-green labor market and social reforms was that they hit people in western Germany as hard as people in eastern Germany, although the latter were affected more by the cutbacks because of the high level of long-term unemployment. Moreover, lower wage growth (below the level of inflation in some years) caused "internal depreciation." This situation, however, had rather

\footnotetext{
9 See the figures on enterprises provided in Berend (2009, p. 61). It should be added, though, that many of these newly self-employed persons took this step because they had lost their jobs. Many of these one-person businesses in trade and retail went out of business when western supermarkets began to spread.

${ }^{10}$ After the turn of the millennium, the flat tax was introduced in all the other postcommunist countries (see Appel and Orenstein, 2018. pp. 90-116; on pension reforms at the global level, see Orenstein, 2009); however, in the aftermath of the 2009 crisis, it was discontinued in many countries.
} 
resulted from the negotiations between employers and trade unions under the Bündnis für Arbeit (Alliance for Work), which was in place from 1998 to 2002, than from the reforms. Even before that time, compromises were frequently made at the enterprise level, in line with the slogan "preserving jobs through pay restraints." This was the contribution corporatist Germany, though much condemned at the time, made to ensuring that German industry could later regain competitiveness.

Most mainstream economists have lauded the long-term effect of the Hartz reforms. But the reforms had a negative effect on social and regional disparities. Social inequality in Germany rose from its original level, which almost matched levels observed in Scandinavia, to levels comparable with those recorded in other postcommunist countries, such as Hungary or Poland. Germany's Gini coefficient, the international standard measure of income inequality, went up from 0.25 in 1999 to 0.29 in the 2009 crisis year. ${ }^{11}$ While these developments cannot be traced to one single factor such as Hartz IV, it is indisputable that the social and labor market reforms increased fears of social decline. This was, in fact, the intention: The threat of poverty was to motivate people to take on jobs that were badly paid and for which they had to commute much further.

This negative mobilization, which took on an even greater dimension in the poorer postcommunist countries, may have contributed to the subsequent "German job miracle," but at the same time, it caused uncertainty among broad segments of society. This is where we find the underlying reasons for the high numbers of votes for the right-wing populist party Alternative for Germany (AfD) in eastern Germany: In Saxony, the AfD even came in strongest in the 2017 parliamentary elections, beating the CDU by a narrow margin. For Germany, this was a political shock which, however, comes as less of a surprise when comparing the former GDR with Poland, the Czech Republic or Slovakia. Both here and there, it was not only the "transformation losers" that voted for populist parties but also middle class voters who were now better off than before, but who remembered former unemployment and social decline and were afraid - not least on account of the so-called refugee crisis and its instrumentalization by right-wing populists - that things might change and they might have to face social cutbacks yet again. ${ }^{12}$

The fundamental problem here, as with the EU as a whole, is that the current economic order is beneficial particularly to those countries, regions and social groups that already are well positioned. Other parts of Europe and its societies, by contrast, are falling behind and have poor economic prospects.

In some ways, Hartz IV meant a reversal of the 1990 strategy. While monetary union aimed for a swift westernization, Hartz IV and, above all, the newly introduced low-wage sector (e.g. Ein-Euro-Jobs, which implied an hourly rate of EUR 1) led to an adjustment of labor costs to wages that were common in Poland and the Czech Republic at the time. This is yet another example of how the united Germany was cotransformed. The very concept of a low-wage sector, however, was developed by Chicago School economists and tested in the 1980s in the "Rust-Belt" states of the U.S.A. Later, the experiment was discarded because it did not yield the desired results.

${ }^{11}$ The data quoted here for Scandinavia and CESEE are accessible at www.gini-research.org/articles/cr. The respective country reports also provide information on the type of data collection. For details on the social impacts of the Hartz reforms, see i.a. Dörre et al. (2015).

${ }^{12}$ For details, see one of the most perceptive books published recently among the many contributions on populism: Manow (2018, p. 94). 
The Hartz reforms, however, did little to ease the predicament of the five "new Länder.” This was, among other things, due to the fact that labor market activation the unemployed were now called "job seekers" - did not help much in regions where there were no or hardly any jobs. There, the government had no other option than to support the unemployed, send them into early retirement or occupy them through job creation measures. This continued to be costly; in total, net transfer payments from western to eastern Germany in the 25 years from 1989 to 2014 came to EUR 1.6 trillion (in this case, "net" means that return flows from eastern to western Germany and transfers to the federal budget, e.g. through taxes collected from eastern Germans, are taken into account). ${ }^{13}$ In record years, net transfer payments amounted to up to EUR 100 billion, which were spent on modernizing infrastructure, privatization and, above all, social benefits.

Despite these flows of funds, the "new Länder" only generated roughly twothirds of western German GDP per capita in 2015 (these figures are based on collated economic data for the five "new Länder"; for details, see the extended new edition of Ther, 2016a). ${ }^{14}$ The Czech Republic, which had to cope without the support of a "big brother" in the West, reached almost the same degree of economic power - without the transfer payments mentioned earlier.

\section{Summary and conclusions}

Germany's history since the fall of the Berlin Wall gives rise to critical questions on various topics - the neoliberal reform concepts of the early 1990s and the early 2000 s on the one hand, and the effectiveness of government spending programs on the other. Moreover, any critical examination should also deal with the long-term consequences of the massive uncertainty that was created within society by mass unemployment, the high rates of East-West migration and the way the German public has dealt with these issues since 1990. This applies not only to the former GDR, but to all new EU Member States where economic reforms - irrespective of their economic assessment - came at a price, both politically and socially. Obviously, not enough people have profited from the reforms (see Milanovic, 2013). One consequence of these disparities has been a drastic increase in labor migration from East to West.

It would be too simple, however, to trace any later successes or problems to the shock therapy Germany went through. Moreover, countries that hesitated to implement reforms in the early 1990s (like Romania, Bulgaria or Ukraine) did not fare any better. Still, the argument by Shleifer and Treisman (2014) that there was a direct causal link between the radical reforms and subsequent economic growth

${ }^{13}$ The figure of EUR 1.6 trillion is quoted from Kühl (2014). The problem with these estimations is that the German federal government has not collected exact statistical data on transfer payments since 1999. Transfer payments also comprise reconstruction aid (which, in some cases, could also be applied for in western Germany) and special benefits, e.g. special economic promotion programs. A comprehensive calculation of all individual types of payments and return flows can be found in Blum et al. (2009).

${ }^{14}$ The calculations provided in Ther (2016a), in turn, are based on data on the so-called NUTS2 regions, which are available from Eurostat at ec.europa.eu/eurostat $/ \mathrm{tgm} / \mathrm{table}$.do? tab=table\&init=1\&language=en\&pcode= tgs00006\&plugin $=1$ (retrieved on November 11, 2018). Eurostat data are updated regularly; the last census in Germany, for example, entailed adjustments as population figures were corrected downward and thus GDP per capita had to be corrected upward. Of course, there are other economic data that are more comprehensive than GDP data, e.g. the Human Development Index (HDI); but only GDP data have been collected regularly also at the regional and local level (according to NUTS3 regions, inter alia) since 1989; this is why Ther (2016a) and this article refer mostly to GDP data. 
- in terms of cause and effect - cannot be upheld. There were other factors that also played a decisive role in the course of economic transformation, such as timing: The forerunners of reform had an enormous initial advantage, as had those countries that had already permitted private businesses to a greater extent in the 1980s. Another equally important factor was the geographical proximity to Western European markets; production was rather moved to postcommunist countries located closer to Western Europe than to countries farther off. Irrespective of these factors, educational levels were comparably high across all postcommunist countries (a fact that was woefully ignored during the time of transformation), experts were well trained and wage levels were low. This is not to say that good or bad economic policies did not play a role. But the argument that the shock therapy was at the root of all subsequent economic success does not hold, as the examples of eastern Germany and Poland show.

Moreover, if we only told a success story, we would disregard the problems that occur when building democracies, as exemplified in the populist revolt that took place in the 2001 and 2005 elections in Poland or in the protest votes for the postcommunist Party of Democratic Socialism (PDS) in eastern Germany. The global financial crisis of 2009 and the euro crisis of 2011 called into question the teloi of transformation: the pure doctrine of market economy, liberal democracy and the desired convergence with the West. With the annus horribilis of 2016 (majority of pro-Brexit votes in British EU referendum, Donald Trump elected President of the United States, defeat of the reformatory left in the Italian constitutional referendum), we have entered a new era. Since then, "the West" as a relatively homogeneous community of values that had been in place since the end of World War II has ceased to exist. In this respect, transformation - which after 1989 had been understood to be teleologically designed - has come to an end. The core countries of liberal capitalism - England and the U.S.A. - have become increasingly protectionist; parliamentary democracy and the rule of law have been weakened; European integration has almost come to a standstill or is being scaled back; and even the word "reform" has widely fallen into disrepute. All this is happening in an economic context that is actually characterized by a generally buoyant global economy. We do not know what might happen politically if there were a recession or a strong rise in interest rates. But as we have seen from the 1989 experience, each change also holds an opportunity.

\section{References}

Appel, H. and M. Orenstein. 2018. From Triumph to Crisis. Neoliberal Economic Reform in Postcommunist Countries. Cambridge: Cambridge University Press.

Arendt, H. 1963. On Revolution. New York: Viking Press.

Balcerowicz, L. 1989. Albo szybko, albo wcałe. In: Polityka 33(48). December.

Balcerowicz, L. and J. Baczyński. 1992. 800 Dni Szok Kontrolowany. Warsaw: Polska Oficyna Wydawnicza.

Berend, I. T. 2009. From the Soviet Bloc to the European Union. Cambridge: Cambridge University Press.

Blum, U. et al. 2009. Regionalisierung öffentlicher Ausgaben und Einnahmen - Eine Untersuchung am Beispiel der Neuen Länder. IWH special issue 4. Halle: Institute for Economic Research.

Böick, M. 2018. Die Treuhand. Idee - Praxis - Erfahrung 1990-1994. Göttingen: Wallstein. 
Borkowski, M. 1988. Sprzedać, oddać, wydzierżawić. In: Polityka 32(49). December.

Butterwegge, C. 2015. Hartz IV und die Folgen. Auf dem Weg in eine andere Republik? Weinheim/Basel: Beltz Juventa.

Diewald, M., A. Goedicke and K. U. Mayer (eds.). 2006. After the Fall of the Wall. Life Courses in the Transformation of East Germany. Stanford: Stanford University Press.

Dörre, K., K. Scherschel, M. Booth, T. Haubner, K. Marquardsen and K. Schierhorn. 2013. Bewährungsproben für die Unterschicht? Soziale Folgen aktivierender Arbeitsmarktpolitik. Frankfurt: Campus.

The Economist. 1999. The sick man of the euro. June 3. www.economist.com/node/209559 (retrieved on May 5, 2014).

Ffrench-Davis, R. 2010. Economic Reforms in Chile. From Dictatorship to Democracy. London: Palgrave Macmillan.

Fukuyama, F. 1989. The end of history? In: The National Interest 16. Summer. 3-18.

Heilbroner, R. 1989. The triumph of capitalism. In: The New Yorker. January 23.

Kołodko, G. 2000. From Shock to Therapy. The Political Economy of Postsocialist Transformation. Oxford: Oxford University Press.

Kühl, J. 2014. 25 Jahre deutsche Einheit: Annäherungen und verbliebene Unterschiede zwischen West und Ost. July 4. www.bpb.de/politik/innenpolitik/arbeitsmarktpolitik/55390/25-jahre-deutsche-einheit? $\mathrm{p}=$ all (retrieved on February 20, 2019).

Lipton, D. and J. D. Sachs. 1990. Poland's economic reform. In: Foreign Affairs 3(69). 47-66.

Manow, P. 2018. Die politische Ökonomie des Populismus. Berlin: Suhrkamp.

Martens, B. 2010. Zug nach Westen - Anhaltende Abwanderung. March 30. www.bpb.de/geschichte/deutsche-einheit/lange-wege-der-deutschen-einheit/47253/zug-nach-westen? $p=a l l$ (February 20, 2019).

Milanovic, B. 2013. Reform and inequality in the transition: An analysis using panel household survey. In: Roland, G. (ed.). Economies in Transition. The Long Run View. London: Palgrave Macmillan. 84-108.

Norkus, Z. 2012. On Baltic Slovenia and Adriatic Lithuania. A Qualitative Comparative Analysis of Patterns in Post-Communist Transformation. Budapest: CEU Press.

Orenstein, M. 2009. Privatizing Pensions. The Transnational Campaign for Social Security Reform. Princeton: Princeton University Press.

Ritter, G. A. 2006. Der Preis der deutschen Einheit. Die Wiedervereinigung und die Krise des Sozialstaates. Munich: C.H.Beck.

Shleifer, A. and D. Treisman, 2014. Normal Countries. The East 25 Years After Communism. In: Foreign Affairs 93(6). https://www.foreignaffairs.com/articles/russia-fsu/2014-10-20/normal-countries (retrieved on May 17, 2019).

Sinn, G. and H.-W. Sinn. 1992. Kaltstart. Volkswirtschaftliche Aspekte der deutschen Vereinigung. Tübingen: dtv.

Ther, P. 2016a. Die neue Ordnung auf dem alten Kontinent. Eine Geschichte des neoliberalen Europa. Berlin: Suhrkamp.

Ther, P. 2016b. Neoliberalismus, Version: 1.0. In: Docupedia-Zeitgeschichte. docupedia.de/zg/ ther_neoliberalismus_v1_de_2016 (retrieved on February 2, 2019).

wiiw. 2012. wiiw Handbook 2012. Vienna: wiiw. 